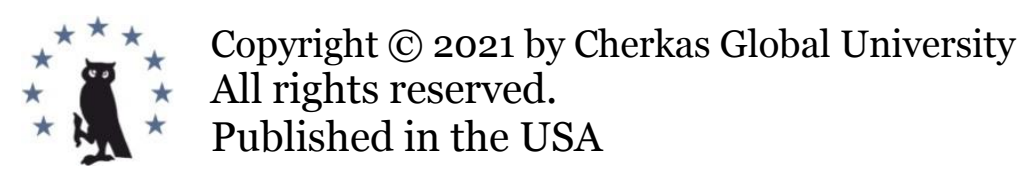

European Journal of Contemporary Education

E-ISSN 2305-6746

2021. 10(4): 1003-1012

DOI: $10.13187 /$ jced.2021.4.1003

https://ejce.cherkasgu.press

IMPORTANT NOTICE! Any copying, reproduction, distribution, republication (in whole or in part), or otherwise commercial use of this work in violation of the author(s) rights will be prosecuted in accordance with international law. The use of hyperlinks to the work will not be considered copyright infringement.

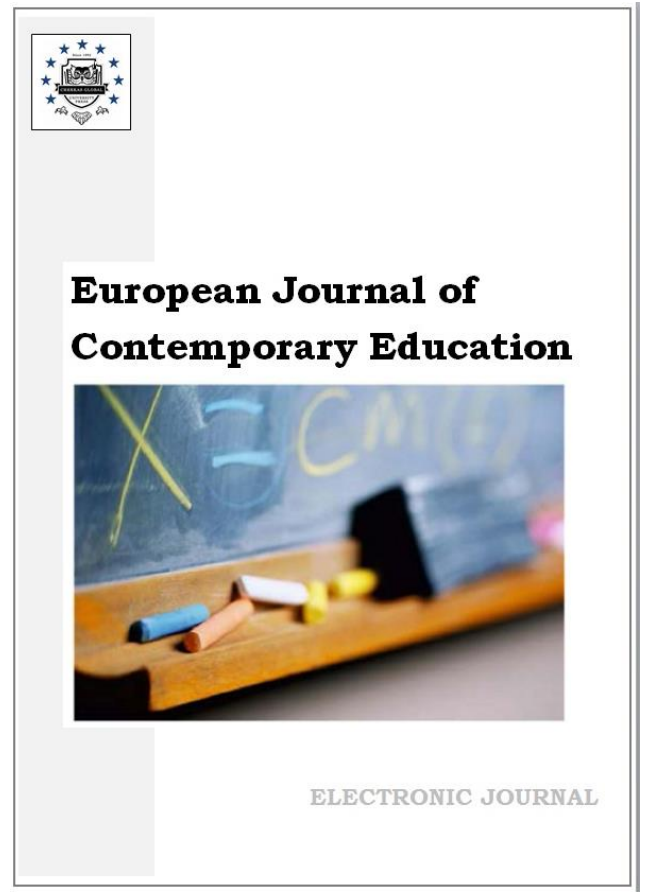

\title{
Psychological and Pedagogical Bases of Standardization of Digital Educational Products and Digital Technologies
}

\author{
Elena A. Sorokoumova ${ }^{a}{ }^{*}$, Elena I. Cherdymova ${ }^{b}$, Elena B. Puchkova a , Larisa V. Temnova ${ }^{c}$ \\ ${ }^{a}$ Moscow Pedagogical State University (FSBEI VO MPGU), Moscow, Russian Federation \\ b Samara National Research University named after Academician S.P. Koroleva \\ (Samara University, SSAU), Samara, Russian Federation \\ ${ }^{c}$ Lomonosov Moscow State University, Moscow, Russian Federation
}

\begin{abstract}
This article is aimed at the analysis of the features of the ecosystem of the digital educational environment. As a research method the testing method was used, which allows to effectively determine the complex of personal determinants of the personality of a pupil as a subject of educational activity, which are important for his psychological safety when using digital educational technologies and digital educational products. The article describes the peculiarity of the current stage of development of the practices of using digital educational technologies and digital educational products in the school educational process. The authors analyzed the psychological and pedagogical foundations of standardization of digital educational products and digital technologies in the educational environment of the school. The authors of the article for the first time - investigated the digital education ecosystem and identified psychological and pedagogical requirements for the use of digital educational products and digital technologies in the educational process. The following psychological and pedagogical requirements are defined: compliance of digital educational technologies and digital educational products with a zone of child's immediate development; taking into account the leading activity in each age period when using digital educational technologies and digital educational products; taking into account specific psychological neoplasms of students at each age stage; taking into account the need for compliance of digital educational products and digital technologies with students' self-knowledge through understanding and finding personal meanings; the safety of digital educational technologies and
\end{abstract}

\footnotetext{
* Corresponding author

E-mail addresses: cea51@mail.ru (E.A. Sorokoumova), cheiv77@mail.ru (E.I. Cherdymova), eb.puchkova@mpgu.su (E.B.Puchkova), temnova.larisa@yandex.ru (L.V.Temnova)
} 
digital educational products for the physical, psychological and social health of participants of the educational process.

Keywords: digital educational technologies, digital educational products, students, digital education ecosystem.

\section{Introduction}

The world has changed significantly over the past decades, and the Internet has played a leading role in this change. He transformed many social relations including the field of education. Consumers of educational services have become much more aware of the possibilities of choosing educational institutions, educational technologies and products. They have formed new high expectations from the educational services they consume and - the most important - information. (Volodin, 2002; Mironov, 2005; Nazarchuk, 2002; Yuldasheva, 2012; Borisov, 2001).

With regard to information, these expectations consist primarily in its presentation through new digital technologies. M. Castels laid a new economy as the foundation of a new society based on knowledge and, accordingly, on the most advanced technologies and culture of real virtuality.

The meaning of such culture is to immerse the real world into the virtual, their mutual interweaving. The lack of established contact between the worlds means a break in communication and death of the acting subject. M. Castels in his works emphasizes the network structure of the knowledge society, and therefore even replaces the concept of the information society with the network society (Castels, 2004). He also transfers this network feature to the field of education. The specificity of the network society in the context of education is manifested in the use of virtual space, visualization and distance technologies in the educational process. The network will eventually replace the teacher's monopoly, and collective forms of education will begin to develop in the digital environment of virtual communities (Castels, 2001).

The theoretical and methodological foundations in the field of the knowledge society and the role of education and communication have been considered in the works of many scientists. (Andreeva, 2002; Bespalko, 2002; Nazalchuk, 2002; Bauman, 2004; Slikishina, 2012). Among the researches of the last decade, the issues of information society, digital communication and education are dealt with (Weindorf-Sysoeva, 2013; Puchkova, 2019; Sorokoumova, 2019; Kuzhevskaya, 2019; Rabinovich, 2020). The role of the information and educational environment in digital communication, as well as issues of digital knowledge management in educational institutions is considered in various works (Voiskunsky, 2002; Ignatiev, 2008; Leshchinsky, 2011; Makarov, 2016; Kozlova, 2018; Mikhaleva, 2019). The quality and content of education, its compliance with modern requirements, determine the level of intellectual potential of society. Thus, in order for the country to complete the transition to the information society, it is necessary to meet a number of parameters, one of which is the digital informatization of education.

The process of informatization of society involves the global and widespread use of information as public resource. The public nature of information is determined by the fact that information, unlike other resources, is not depleted in the process of its consumption, its quantity remains the same. For the participants of the educational process, this is not so much a whim as a necessity due to the specifics of the new information society, the huge amounts of new data that accompany a person every day (Sorokoumova, 2019; Puchkova, 2019; Temnova, 2019).

At all times, researchers saw problems and ideas in the education system that were questioned and criticized, new views on the learning process were proposed, relative to their time. Scientists sought to describe the essence of education as a social phenomenon, its place in public life and its dependence on the social way of life (Angelovsky, 1991; Churekova, 2001; Markov, 2003; Myasnikov, 2006; Dzyatkovskaya, 2016).

Some of the ideas of the classics regarding education still remain relevant, although the context of their application has significantly transformed in the digital society. In the context of globalization, the development of information and communication technologies determines the essence of social transformations in the field of education. In our opinion, special attention should be paid to the ecosystem of the educational environment.

The ecosystem of the educational environment is a stable interrelation of all subjects involved in the process of education and upbringing. The digital educational environment includes digital technologies and products that can significantly affect the stability of the educational ecosystem, changing and transforming it, affecting the interaction of participants in the learning and 
upbringing process with each other (Cherdymova, 2021). By digital educational technologies we mean a way of organizing the educational environment based on modern information technologies translated into electronic format using computers, tablets, other gadgets and Internet resources. Digital educational products are the result of the work of an individual or a group of persons, expressed in the form of a digital educational product and a digital educational service (metadigital educational complexes, online platforms, remote classes, computer programs, electronic textbooks, audio and video lectures, electronic notes, multimedia presentations, game simulators, etc.) (Cherdymova, 2021).

Modern digital learning is based on the principle of active learning, unlike traditional. Students not only receive knowledge in a ready-made form, but also participate in the process of obtaining new knowledge. The main responsibility in this case falls on the students, and not on the teacher. Digital education is becoming particularly relevant with the introduction of thirdgeneration federal state standards and related reductions of classroom work and the expansion of forms of independent learning using digital educational technologies and digital educational products, but the psychological and pedagogical foundations of standardization of digital educational products and digital technologies have not been worked out yet.

Today's educational guidelines are focused on improving the organizational methods of the educational process, we, in turn, pay attention to the psychological and pedagogical foundations of standardization of digital educational products and digital technologies, using the causal approach described in the works of A.F. Anufriev The causal approach has a number of prerequisites for its emergence. First of all, this is a theoretical and methodological analysis of psychodiagnostics, conducted in the works of L.S. Vygotsky and the idea that any mental process should be considered as a part of a specific activity (practical or mental), and according to which every external activity of a living being contains mental components through which its regulation is carried out (Anufriev, 2019).

Taking into account the ideas of L.S. Vygotsky about a zone of proximal development (Vygotsky, 1935), one of the psychological and pedagogical requirements for the standardization of digital educational products and technologies can be their compliance with a zone of proximal development of a child, and this applies to all higher mental functions (memory, attention, thinking, etc.), and refers to multifunctional mental formations (intelligence, arbitrariness, awareness of action), skills (literacy, reading). Moreover, L.S. Vygotsky notes that the concept of a zone of prroximal development is applicable to different aspects of the child's personality, that, undoubtedly, should be taken into account when using digital educational technologies and digital educational products (Vygotsky, 1984).

In our opinion, the standardization of digital educational products and digital educational technologies should also be based on the ideas about leading activities developed by A.N. Leontiev and taken by D.B. Elkonin as a basis for considering the periodization of personal development. As A.N. Leontiev said about the leading activity, that each stage of mental development is characterized by the certain, leading at this stage, child's attitude to reality, the certain, leading type of his activity, therefore, it is necessary to talk about the dependence of the development of the psyche not on activity in general, but on the leading activity. This is an activity in which private mental processes are formed or rebuilt, on which the main psychological changes of the child's personality observed during the period of development, this is an activity which development determines the most important changes in the mental processes and psychological features of the child's personality at this stage of his development (Leontiev, 1983). D.B. Elkonin emphasized that each age, as a peculiar and qualitatively special period of a person's life, is characterized primarily by a certain type of leading activity and specific psychological neoplasms that arise due to it. All three epochs - early childhood, childhood, adolescence - are built on the same principle and consist of two periods that are naturally connected. The transition from one epoch to the next occurs when there is a discrepancy between the operational and technical capabilities of a child and the tasks and motives of activity on the basis of which they were formed. The periods in which there is a predominant development of the motivational and need sphere are naturally followed by periods in which there is a predominant formation of operational and technical capabilities of children, and vice versa (Elkonin, 1971).

Therefore, the basis of the psychological and pedagogical requirement for the standardization of digital educational products and digital technologies can be put forward the requirement to take 
into account the leading activity in each age period. And the requirement to take into account specific psychological neoplasms of students at each age stage.

Taking into account the ideas of E.A. Sorokoumova about the psychology of self-knowledge in learning, we consider self-knowledge as a process of development and enrichment of consciousness. Self-knowledge is the process of gaining knowledge about oneself by distinguishing oneself from others, identifying and separating oneself from other people based on comparing oneself with them and with oneself in the past, present and distant future. Self-knowledge becomes a starting point for the consolidation and unity of people, regardless of their views, life positions, guidelines, life philosophy. The psychological mechanism of self-knowledge is understanding as a process and result of finding, generating and interpreting the personal meanings of the subjects of interaction, learning and communication (Sorokoumova, 2010). On the basis of this information, the following psychological and pedagogical requirement should be put forward for the standardization of digital educational products and technologies about the need for digital educational products and digital technologies to correspond to students' self-knowledge through understanding and finding personal meanings. Semantic attitudes provide an individual with familiarization with the system of norms and values, self-defense and self-affirmation of the individual in the digital educational space.

In addition to these requirements, the undoubted requirement for digital educational products and digital educational technologies is the requirement for their safety for the health of the student. A.A. Verbitsky, the author of the theory of contextual education, pointed out that thinking speech is born only through live dialogical communication of a child with his mother, a student with a teacher, etc. "Leaving a child and even an adult alone with a computer leads to the fact that both speech and thinking suffer, they simply do not form and do not develop. And the dialogue with a computer is just a metaphor" (Verbitsky, 2016).

Thus, it should be noted that the digital educational ecosystem is one of the central categories of the modern educational process, which should correspond not only to the acquisition of knowledge by students, but also not harm the psychological, physical and social health of participants of the educational process.

\section{Materials and methods}

In order to verify the need to take into account all above-mentioned psychological and pedagogical foundations of standardization of digital educational products and digital technologies, we conducted the research aimed at identifying a set of personal determinants of a pupil, important for his psychological security in the Internet space.

The problem of the research is the existing contradiction between the digital technologies and products used in the educational practice that do not have standards of use today, and the psychological safety of students in whose training these digital technologies and products are used.

The purpose of the research is to determine the complex of cognitive and personal qualities of a younger student that contribute to his psychological security in the Internet space, that, in turn, can act as the psychological and pedagogical criteria for standardization of digital technologies and products.

At the first stage of the research, a theoretical and methodological analysis of issues related to the problems of psychological security in the Internet space was carried out.

At the second stage, the compilation of methodological tools that meet the purpose of the research was carried out.

At the third stage, the personal determinants of the psychological security of pupils in the Internet space were studied.

The primary sample consisted of 170 primary school students, $47 \%$ of them - boys and $53 \%$ - girls. The sample of the participants was formed taking into account the following parameters: 1) digital educational technologies and products are used in the educational process beginning from the first year of study; 2) all the students have experience of distance learning during the period of the forced quarantine due to the pandemic; 3) all the students study according to the same educational program. After the survey, two additional selection criteria were applied to the entire sample: a) the results of students' education meet the requirements of basic general education: based on the analysis of academic performance, students whose average academic performance score is 4 are selected; b) the absence of signs of Internet addiction among the schoolchildren that 
was determined on the basis of a questionnaire constructed according to the method of "Diagnostics of Internet addiction" by K. Yang (adaptation by V.A. Burova) in an abbreviated form.

After the additional selection of the participants and in order to test the empirical hypothesis about the presence of significant differences between the subgroups of the sample, two groups were identified: a) group $1-2^{\text {nd }}$ grade students (58 participants) aged 8-9 years; b) group $2-4^{\text {th }}$ grade students (45 participants) aged 10-11 years.

For the psychodiagnostic examination the following methods were used (Rogov, 1999; Raygorodsky, 2011; Sorokoumova, 2015):

1. The questionnaire to identify the features of digital communication of students in the Internet environment.

2. The Phillips' School Anxiety Questionnaire.

3. The Dembo-Rubinstein's method of self-esteem diagnostics. Modification of the Parishioners.

4. The Kuhn's test. The Test "Who am I?" (M. Kuhn, T. McPartland; modification by T.V. Rumyantseva).

5. The Method of "Simple analogies".

6. The D. Lampen Method "Tree" in the adaptation by L.P. Ponomarenko

Verification of the results of the participants for the normality of the data distribution was carried out using the Kolmogorov-Smirnov criterion. The data are distributed according to the normal law, the search for significant differences was carried out according to the mathematical coefficient of the Manna-Whitney.

\section{Results}

The analysis of the results of the empirical research is presented in accordance with each psychodiagnostic technique and the data of the search for significant differences between the subgroups of the sample.

According to the results of the survey, it was established that the digital communication of students has specific features that distinguish it from the communication in an offline environment; there were no differences between the subgroups of the sample. Let's present the main features of digital communication of students in the Internet environment in Figure 1.

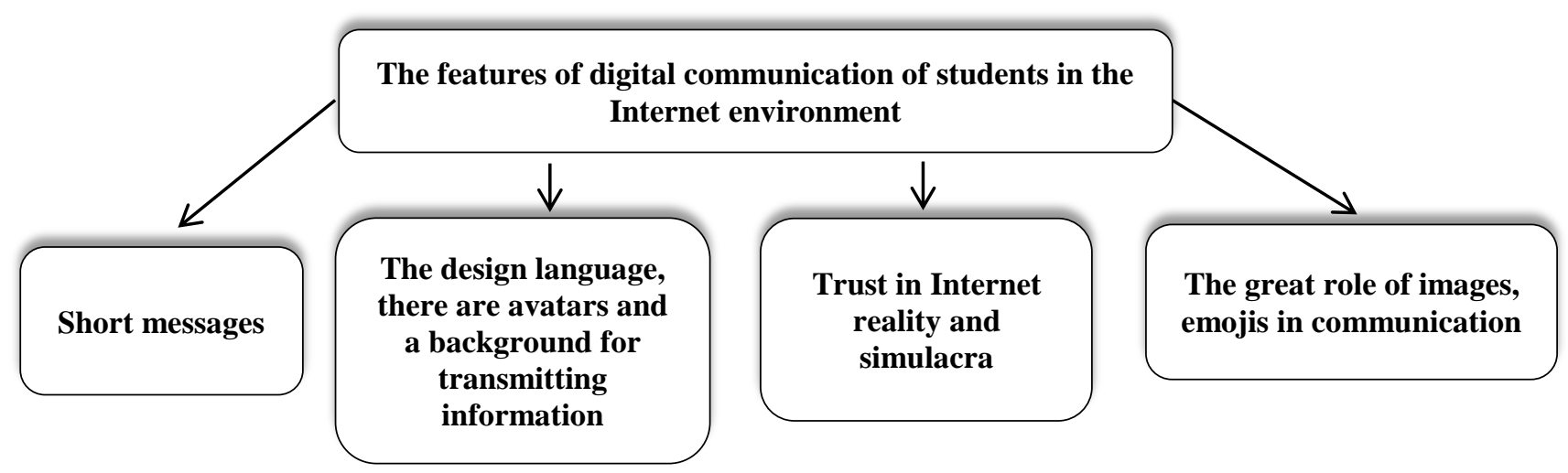

Fig. 1. The features of digital communication of students in the Internet environment

According to the B. Phillips School Anxiety Questionnaire, no significant differences were found between the subgroups of the sample. According to the sample as a whole, a number of parameters should be noted that reduce the psychological safety of schoolchildren: $45 \%$ of them experience fear of self-expression, $41 \%$ of students experience fear of a knowledge test situation, $36 \%$ have a fear of not meeting the expectations of others. Low physiological resistance to stress was detected in $22 \%$ of students.

From the results of the Dembo-Rubinstein Self-esteem Diagnostic Method (modification of A.M. Prikhozhan) no significant differences were found between the subgroups of the sample. The following data were obtained for the sample as a whole: - on the "Mind, Abilities" scale $58 \%$ rate themselves as normal; $33 \%$ have an overestimated self-esteem; $9 \%$ have an underestimated 
self-esteem; - on the "Character" scale $54 \%$ rate themselves as normal; $40 \%$ have an overestimated self-esteem; $6 \%$ have an underestimated self-esteem; - on the "Self-Confidence" scale: $40 \%$ rate themselves as normal; $45 \%$ have an overestimated self-esteem; $14 \%$ have an underestimated self-esteem.

According to the scales of "Peer authority", "Appearance", "The ability to do a lot with one's own hands", the dominant percentage of participants had an overestimated self-esteem. Thus, most of the younger students have the adequate and increased self-esteem.

The search for significant differences in the self-esteem parameter between grades 2 and 4 showed that they are in the zone of insignificance. In addition, the "Who am I?" test was conducted (M. Kuhn, T. McPartland; modification by T.V. Rumyantseva). There were no significant differences in the subgroups of the sample. According to the sample as a whole, it was revealed that $90 \%$ of schoolchildren have the adequate self-esteem and only $10 \%$ of the participants have a self-esteem index below the norm that corresponds to the indicators of the previous diagnostic methodology.

The analysis of the data using the "Simple Analogies" Method among students in grades 2 and 4 showed that in grades 4 there are more students with a low level of cognitive development ( $5 \%)$ and fewer students with a level of cognitive development below average (15\%). There are more students with a high level of cognitive development in grades $2(40 \%)$, and more students with an average level of cognitive development in grades 4 (47\%). The result of the search for significant differences between students of grades 2 and 4 is presented in Table 1.

Table 1. Results of the comparative analysis using the "Simple analogies" method ( $U_{\text {cr }}$ at $p \leq 0,05$; $\mathrm{p} \leq \mathrm{O}, \mathrm{O1})$

\begin{tabular}{|l|c|c|c|c|}
\hline \multirow{2}{*}{ Name of the scale } & \multicolumn{2}{|c|}{ Average values } & \multirow{2}{*}{ U Emp } & Significant \\
\cline { 2 - 3 } & $\begin{array}{c}2^{\text {nd }} \text { differences } \\
(\mathrm{n}=58)\end{array}$ & $\begin{array}{c}4^{\text {th }} \text { grade } \\
(\mathrm{n}=45)\end{array}$ & & Presence \\
\hline $\begin{array}{l}\text { High level of cognitive } \\
\text { development }\end{array}$ & $24 \pm 1,21$ & $11 \pm 1,25$ & 0 & Presence \\
\hline $\begin{array}{l}\text { Average level of cognitive } \\
\text { development }\end{array}$ & $9 \pm 0,96$ & $16 \pm 1,1$ & 0 & Presence \\
\hline $\begin{array}{l}\text { The level of cognitive development } \\
\text { is below average }\end{array}$ & $17 \pm 1,14$ & $6 \pm 1,26$ & 0 & Presence \\
\hline Low level of cognitive development & $8 \pm 1,01$ & $12 \pm 1,08$ & 0 & 0 \\
\hline
\end{tabular}

The presence of significant differences between students of the 2nd and 4th grades at all levels of development of cognitive abilities has been established.

The Method "Tree" by D. Lampen (adaptation by L.P. Ponomarenko) was carried out with an addition to the instructions: the participants were asked to choose a little man who reminds them of themselves in the process of distance learning and independent work with the digital technologies and products. The analysis of the results showed that compared with the 2nd grades (25\%), there are noticeably fewer students in the $4^{\text {th }}$ grades who claim leadership positions (16\%), while there are more students who want to achieve success without an effort on their part (34\%). A slightly less noticeable the decrease in the number of students with normal adaptation and students who are ready to overcome obstacles in the learning process. The search for significant differences is presented in Table 2.

Table 2. Results of the comparative analysis using the "Tree" method $\left(\mathrm{U}_{\mathrm{Cr}}\right.$ at $\left.\mathrm{p} \leq \mathrm{0,05} ; \mathrm{p} \leq \mathrm{0,01}\right)$

\begin{tabular}{|l|c|c|c|c|}
\hline \multirow{2}{*}{ Name of the scale } & \multicolumn{2}{|c|}{ Average values } & \multirow{2}{*}{$\mathrm{U}_{\text {Emp }}$} & Significant \\
\cline { 2 - 3 } & $\begin{array}{c}2^{\text {nd }} \text { grade } \\
(\mathrm{n}=58)\end{array}$ & $4^{\text {th }}$ grade $(\mathrm{n}=45)$ & & \\
\hline Leadership Mindset & $69,0 \pm 1,23$ & $61,9 \pm 1,64$ & 0 & Presence \\
\hline Normal adaptation & $65,9 \pm 1,26$ & $64,7 \pm 1,12$ & 2 & Absence \\
\hline Sociability, friendly support & $69,0 \pm 1,23$ & $68,4 \pm 1,26$ & 3 & Absence \\
\hline Desire to achieve success without & $61,9 \pm 1,64$ & $64,8 \pm 1,71$ & 0,5 & Absence \\
\hline
\end{tabular}




\begin{tabular}{|l|c|c|c|c|}
\hline making an effort & & & & \\
\hline Detachment & $68,8 \pm 1,24$ & $66,3 \pm 1,36$ & 1 & Absence \\
\hline Mindset for overcome obstacles & $66,8 \pm 1,53$ & $62,7 \pm 1,13$ & 0 & Presence \\
\hline Motivation for entertainment & $74,2 \pm 1,18$ & $70,4 \pm 1,26$ & 0 & Presence \\
\hline
\end{tabular}

According to the scales "Leadership Mindset", "Mindset for overcome obstacles", "Motivation for entertainment", significant differences were revealed between students of the 2nd and 4th grades. We can state a twofold trend that with the increase in learning experience with the use of digital technologies and products, both positive personal characteristics (leadership mindset, mindset for overcoming obstacles) and negative ones (motivation for entertainment) are developed.

\section{Discussion}

Based on the results of the research, it can be concluded that digital technologies and digital products in the learning process for this category of students were used prematurely, this led to the emergence of risks of developmental disorders. Therefore, one of the conditions for the use of digital technologies in education should be taking into account the stages of age-related development. Also, the obtained data indicate a decrease in personal characteristics that ensure the success of mastering the program material and the overall development of students.

Taking into account the fact that students with a level of cognitive development below average are at risk, it can be assumed that the most vulnerable category of students are children with special health opportunities and developmental disabilities. The use of digital technologies in the learning process becomes for them possible only when taking into account their zone of closest development according to Vygotsky.

One of the challenges to traditional education and an incentive for the transition to digital communication was the rapid development of education using digital educational technologies and digital educational products. The digital environment is focused on a person who is capable of selforganization in order to acquire knowledge and skills. The basis of education using digital educational technologies and digital educational products is distance learning, which assumes the presence of digital environment as an intermediary between a teacher and a student. Gamification of education has particular interest in education due to the use of digital educational technologies and digital educational products as a way to resolve the contradictions between the desire to play and the unwillingness to learn and perform routine actions. The reasons for introducing game elements into education are diverse: knowledge is easier to learn in the game; the game causes a state of pleasure, time flies imperceptibly in it; players communicate on an equal footing, without hierarchies of relationships; progress is visible in the game and there is reinforcement with rewards.

The digital information and educational environment can provide the greatest assistance in mastering the skills that are in demand today in the context of educational organizations. The educational environment with the use of digital educational technologies and digital educational products is a systematized set of educational, methodological, organizational, informational and technical conditions aimed at the educational process and its participants. Its main goal is to improve the quality and accessibility of education, create conditions for the development of creative potential and professional and personal formation.

\section{Conclusion}

In addition to the adapted digital infrastructure, the educational environment with the use of digital educational technologies and digital educational products also includes a psychological aspect - the result of professional and cohesive activity of a team of teachers and other employees of an educational institution, their readiness and ability to participate in the formation of the digital education ecosystem.

As a result of the conducted empirical research, the following conclusions can be drawn:

- a number of parameters have been identified that increase the psychological safety of younger schoolchildren: an adequate self-assessment of their mind, abilities and character, as well as an increased self-assessment of their authority among peers, self-confidence, their appearance and the ability to do a lot with their own hands; 
- a number of parameters have been identified that reduce the psychological safety of schoolchildren: fear of self-expression, fear of a knowledge test situation, fear of not meeting the expectations of others, low physiological resistance to stress;

- with an increase of the experience of learning with the use of digital technologies and products, both positive personal characteristics (leadership mindset) and negative ones (desire to achieve success without making an effort) are developed.

\section{Recommendations}

Standardization of digital educational products and digital technologies should be based on the identified psychological and pedagogical foundations:

- compliance with the zone of the child's closest development, and this applies to all higher mental functions (memory, attention, thinking, etc.), and this also applies to multifunctional mental formations (intelligence, arbitrariness, awareness of action), skills (literacy, reading);

- compliance with the leading activity of each age period;

- compliance with the specifics of psychological neoplasms of students at each age stage;

- availability of conditions for the development of self-knowledge of students through understanding and finding personal meanings;

- the presence of safety for the physical, psychological and social health of participants in the educational process.

Thus, in order for learning with the use of digital educational technologies and digital educational products to personify and differentiate the educational process, to increase the motivation of learning, to ensure effective and prompt communication between all the participants in the educational process and to positively affect the quality of education, it is necessary to take into account all of the above psychological and pedagogical foundations.

The psychological and pedagogical foundations of standardization of digital technologies and products in the educational process contribute to the formation of the ecosystem of the digital educational environment. In this regard, the work on the formation of the digital education ecosystem should contain propaedeutic and preventive work with teachers, students and their parents aimed at preventing violations of physical, psychological and social health.

\section{Acknowledgments}

The research was carried out within the framework of the implementation of the scientific research "Development of psychological and pedagogical foundations for standardization of digital educational products/technologies" by the Moscow State Pedagogical University in 2021 at the expense of the federal budget.

\section{References}

Andreeva, 2002 - Andreeva, I.N. (2020). Istoriya obrazovaniya i pedagogicheskoi mysli za rubezhom i v Rossii. Ucheb. posobie dlya stud. vyssh. ped. ucheb. zavedenii [History of education and pedagogical thought abroad and in Russia. Study guide for students of higher ped. institutions]. M.: Akademiya, 416 p. [in Russian]

Angelovsky, 1991 - Angelovsky, K. (1991). Uchitelya i innovatsii: Kniga dlya uchitelya. [Teachers and innovations: Book for teachers]. M: Prosveshchenie, 159 p. [in Russian]

Anufriev, 2019 - Anufriev, A.F. (2019). Poiskovye tekhnologii obucheniya v psikhologicheskom obrazovanii [Search technologies of training in psychological education]. Innovatsii $v$ obrazovanii. 1: 79-91. [in Russian]

Bauman, 2004 - Bauman, Z. (2004). Globalizatsiya. Posledstviya dlya cheloveka i obshchestva [Globalization. Consequences for a man and society]. M: Logos, 326 p. [in Russian]

Bespalko, 2002 - Bespalko, V.P. (2002). Obrazovanie i obuchenie s uchastiem komp'yuterov (pedagogika tret'ego tysyacheletiya) [Education and training with the participation of computers (pedagogy of the third millennium)]. M: Izd-vo Moskovskogo psikh.-sots. instituta; Voronezh: Izdvo NPO «Modek». 352 p. [in Russian]

Borisov, Khokhlova, 2001 - Borisov, N.V., Khokhlova, Yu.E. (2001). Razvitie informatsionnogo obshchestva $\mathrm{v}$ Rossii [The development of the information society in Russia]. T. 1. Teoriya i praktika. SPb.: Izd-vo S.-Peterb. un-ta, 240 p. [in Russian] 
Castels, 2001 - Castels, M. (2001). Informatsionnaya epokha: ekonomika, obshchestvo i kul'tura [The Information Age: Economy, Society and Culture]. M: M.: GU-VShE, 201 p. [in Russian]

Castels, 2004 - Castels, M. (2004). Galaktika Internet: Razmyshleniya ob Internete, biznese i obshchestve [The Galaxy of the Internet: Reflections on the Internet, Business and Society]. Ekaterinburg: U-Faktoriya, 200 p. [in Russian]

Churekova, 2001 - Churekova, T.M. (2001). Nepreryvnoe obrazovanie i razvitie lichnosti v sisteme innovatsionnykh uchebnykh zavedenii [Continuing education and personal development in the system of innovative educational institutions]. Kemerovo: Kuzbassvuzizdat, 149 p. [in Russian]

Dzyatkovskaya i dr., 2016 - Dzyatkovskaya, E.N., Zakhlebny, A.N., Gneusheva, T.A. (2016). Podkhod k opredeleniyu indikatorov obrazovaniya dlya ustoichivogo razvitiya [The approach to determining indicators of education for sustainable development]. Standarty $i$ monitoring $v$ obrazovanii. 2: 11-17. [in Russian]

Elkonin, 1971 - Elkonin, D.B. (1971). K probleme periodizatsii psikhicheskogo razvitiya v detskom vozraste [On the problem of periodization of mental development in childhood]. Voprosy psikhologii. 4: 63-71. [in Russian]

Ignatiev, Rozanov, 2008 - Ignatiev, V.I., Rozanov, F.I. (2008). Obrazovanie v informatsionnuyu epokhu [Education in the information age]. Filosofiya obrazovaniya. 2: 76-85. [in Russian]

Kozlova, 2018 - Kozlova, N.S. (2018). Aktual'nost' onlain obrazovaniya dlya IT-spetsialistov [The relevance of online education for IT-specialists]. Vestnik Maikopskogo gosudarstvennogo tekhnologicheskogo universiteta. 4: 80-85. [in Russian]

Kuzhevskaya, Smyk, 2019 - Kuzhevskaya, E.B., Smyk, E.I. (2019). Primenenie distantsionnykh tekhnologii obucheniya $\mathrm{v}$ sovremennom obrazovatel'nom protsesse: za i protiv [Application of distance learning technologies in the modern educational process: pros and cons]. Vestnik ekonomicheskoi bezopasnosti. 3: 376-378. [in Russian]

Leontiev, 1983 - Leontiev, A.N. (1983). Izbrannye psikhologicheskie proizvedeniya [Selected psychological works]. M.: Pedagogika, 190 p. [in Russian]

Leshchinsky i dr., 2011 - Leshchinsky, M.B., Martynenkov, V.V., Pestrikov, A.M., Rudinsky, I.D. (2011). Virtual'no-naturnye obuchayushchie kompleksy dlya podgotovki spetsialistov v oblasti innovatsionnykh tekhnologii [Virtual and full-scale training complexes for training specialists in the field of innovative technologies]. Informatsionnye tekhnologii modelirovaniya i upravleniya. 2(67): 128-134. [in Russian]

Markov, 2003 - Markov, B.V. (2003). Problema cheloveka v epokhu mass-media. Perspektivy cheloveka $\mathrm{v}$ globaliziruyushchemsya mire [The human problem in the era of mass media. Human perspectives in a globalizing world]. SPb.: Sankt-Peterburgskoe filosofskoe obshchestvo, pp. 62-84. [in Russian]

Mikhaleva, 2019 - Mikhaleva, O.V. (2019). Formirovanie kompetentnosti v oblasti mezhkul'turnoi kommunikatsii u budushchikh bakalavrov v usloviyakh tsifrovoi obrazovatel'noi sredy [Formation of competence in the field of intercultural communication among future bachelors in the digital educational environment]: avtoref. dis.... kand. ped. nauk. Moscow, 24 p. [Electronic resource]. URL: http:/www.dslib.net/prof-obrazovanie/formirovanie-kompetentnosti-v-oblasti-mezhkulturnojkommunikacii-u-buduwih.html [in Russian]

Mironov, 2002 - Mironov, V.V. (2002). Kul'tura v prostranstve global'noi kommunikatsii [Culture in the space of global communication]. Vestnik Rossiiskogo filosofskogo obshchestva. 1: 19-24. [in Russian]

Mironov, 2005 - Mironov, V.V. (2005). Informatsionnoe prostranstvo: vyzov kul'ture [Information space: the challenge to culture]. Informatsionnoe obshchestvo. Is. 1. M. Pp. 14-18. [in Russian]

Myasnikov i dr., 2006 - Myasnikov, V.A., Wolfson, B.L., Savina, A.K. (2006). Osnovnye tendentsii razvitiya obrazovaniya $\mathrm{v}$ sovremennom mire [The main trends in the development of education in the modern world]. M, ITIP RAO, 336 p. [in Russian]

Nazarchuk, 2002 - Nazarchuk, A.B. (2002). Etika globaliziruyushchegosya obshchestva [Ethics of the globalizing society]. M: Direktmedia pablishing, 378 p. [in Russian] 
Puchkova i dr., 2019 - Puchkova, E.B., Temnova, L.V., Sorokoumova, E.A., Kurnosova, M.G. (2019). Vzaimosvyaz' tsennostei i kar'ernykh orientatsii sovremennykh podrostkov [The relationship of values and career orientations of modern adolescents]. Psikhologicheskaya nauka $i$ obrazovanie. 5: 27-36. [in Russian]

Rabinovich i dr., 2020 - Rabinovich, P.D., Zavodensky, K.E., Kushnir, M.E., Khramov, Yu.E., Melik-Parsadanov, A.R. (2020). Tsifrovaya transformatsiya obrazovaniya: ot izmeneniya sredstv $\mathrm{k}$ razvitiyu deyatel'nosti [Digital transformation of education: from changing means to developing activities]. Informatika i obrazovanie. (5): 4-14. [in Russian]

Slikishina, 2012 - Slikishina, I.V. (2012). Distantsionnoe obrazovanie - nachalo puti [Distance education - the beginning of the path]. Informatsionno-kommunikatsionnye tekhnologii $v$ pedagogicheskom obrazovanii. 4: 7-9. [in Russian]

Sorokoumova, 2010 - Sorokoumova, E.A. (2010). Psikhologiya samopoznaniya v obuchenii [Psychology of self-knowledge in education: monograph]. M: Moskovskii gosudarstvennyi oblastnoi universitet, 327 p. [in Russian]

Sorokoumova, 2019 - Sorokoumova, E.A. (2019). Samopoznanie detei tsifrovogo pokoleniya $\mathrm{i}$ ikh psikhologicheskoe blagopoluchie $\mathrm{v}$ protsesse obucheniya [Self-knowledge of children of the digital generation and their psychological well-being in the learning process]. Informatsionnokommunikatsionnye tekhnologii $\mathrm{v}$ sovremennom obrazovatel'nom prostranstve M.: OOO «Sam Poligrafist». Pp. 58-66. [in Russian]

Verbitsky, 2016 - Verbitsky, A.A. (2016). "Tsifrovoe pokolenie": problemy obrazovaniya ["Digital generation": problems of education]. Professional'noe obrazovanie. Stolitsa. 7: 10-13. [in Russian]

Verbitsky, 2016 - Verbitsky, A.A. (2016). Teoriya kontekstnogo obrazovaniya kak kontseptual'naya osnova sovremennoi obrazovatel'noi paradigmy [The theory of contextual education as a conceptual basis of the modern educational paradigm]. Scientific and practical reviewed journal. Israeli independent academy of development of science. 8(1): 5-17. [in Russian]

Voiskunsky, 2002 - Voiskunsky, A.E. (2002). Internet - novaya oblast' issledovanii v psikhologicheskoi nauke [The Internet is a new field of research in psychological science]. Uchenye zapiski kafedry obshchei psikhologii MGU. M., Is. 1. Pp. 82-101. [in Russian]

Volodin, Shirokov, 2002 - Volodin, A.G., Shirokov, G.K. (2002). Globalizatsiya: nachala, tendentsii, perspektivy [Globalization: beginnings, trends, prospects]. M: In-t vostokovedeniya RAN, 260 p. [in Russian]

Vygotsky, 1983 - Vygotsky, L.S. (1983). Razvitie vysshikh psikhicheskikh funktsii [Development of higher mental functions]. Sobr. Op. T. 3. M.; L.: Pedagogy, 368 p. [in Russian]

Vygotsky, 1984 - Vygotsky, L.S. (1984). Voprosy detskoi (vozrastnoi) psikhologii [Questions of child (age) psychology]. M.: Pedagogika, 432 p. [in Russian]

Weindorf-Sysoeva, Khapaeva, 2013 - Weindorf-Sysoeva, M.E., Khapaeva, S.S. (2013). Kontseptsiya organizatsii virtual'noi obrazovatel'noi sredy v mnogourovnevoi sisteme podgotovki pedagogicheskikh kadrov dlya E-learning: monogr. [The concept of organizing the virtual educational environment in a multi-level system of training teachers for E-learning: monogr.]. M.: IIU MGOU, 175 p. [in Russian]

Yuldasheva, Okolnishnikova, 2012 - Yuldasheva, O.U., Okolnishnikova, I.Yu. (2012). Personalizatsiya marketingovykh kommunikatsii - orientir adaptatsii marketing-miksa $\mathrm{k}$ trebovaniyam potrebitelei v usloviyakh informatizatsii obshchestva [Personalization of marketing communications - a guideline for adapting the marketing mix to the requirements of consumers in the conditions of informatization of society]. Marketingovye kommunikatsii. 04(70): 204-212. [in Russian] 